Research

Open Access

\title{
Extracorporeal life support in severe drug intoxication: a retrospective cohort study of seventeen cases
}

\author{
Cédric Daubin 1 , Philippe Lehoux², Calin Ivascau³, Marine Tasle², Mehdi Bousta1, Olivier Lepage ${ }^{3}$, \\ Charlotte Quentin ${ }^{1}$, Massimo Massetti ${ }^{3}$ and Pierre Charbonneau ${ }^{1}$
}

\begin{abstract}
1Department of Medical Intensive Care, Caen University Hospital, avenue Côte de Nacre, Caen Cedex 14033, France
2Department of Anesthesiology, Caen University Hospital, avenue Côte de Nacre, Caen Cedex 14033, France

${ }^{3}$ Department of Thoracic and Cardiovascular Surgery, Caen University Hospital, avenue Côte de Nacre, Caen Cedex 14033, France

Corresponding author: Cédric Daubin, daubin-c@chu-caen.fr
\end{abstract}

Received: 27 Apr 2009 Revisions requested: 25 Jun 2009 Revisions received: 22 Jul 2009 Accepted: 25 Aug 2009 Published: 25 Aug 2009

Critical Care 2009, 13:R138 (doi:10.1186/cc8017)

This article is online at: http://ccforum.com/content/13/4/R138

(c) 2009 Daubin et al.; licensee BioMed Central Ltd.

This is an open access article distributed under the terms of the Creative Commons Attribution License (http://creativecommons.org/licenses/by/2.0), which permits unrestricted use, distribution, and reproduction in any medium, provided the original work is properly cited.

\begin{abstract}
Introduction Cardiovascular failure is the leading cause of death in severe acute drug intoxication. In this setting, we report the feasibility, complications, and outcome of emergency extracorporeal life support (ECLS) in refractory shock or cardiac arrest following a drug overdose.

Methods This is a retrospective cohort study of 17 patients admitted over a 10-year period for prolonged cardiac arrest or refractory shock following a drug overdose and not responding to optimal conventional treatment. Patients were evaluated in the medical ICU and cardiovascular surgery department of a university hospital. ECLS implantation used a centrifugal pump connected to a hollow-fiber membrane oxygenator and was performed in the operating room $(n=13)$, intensive care unit ( $n$ $=3)$, or emergency department $(n=1)$. ECLS was employed for refractory shock and prolonged cardiac arrest in 10 and 7 cases, respectively.
\end{abstract}

Results The mean duration of external cardiac massage was $101 \pm 55$ minutes. Fifteen patients had ingested cardiotoxic drugs, including 11 cases of drugs with membrane stabilizing activity. Time from hospital admission to initiation of ECLS was $6.4 \pm 7.0$ hours. Time to ECLS implant was $58 \pm 11$ minutes. The mean ECLS flow rate was $3.45 \pm 0.45 \mathrm{~L} / \mathrm{min}$. The average ECLS duration was $4.5 \pm 2.4$ days. Early complications included limb ischemia $(n=6)$, femoral thrombus $(n=1)$, cava inferior thrombus $(n=1)$, and severe bleeding at the site of cannulation $(n=2)$. Fifteen patients were weaned off ECLS support and $13(76 \%)$ were discharged to hospital without sequelae.

Conclusions Based on our experience, we consider ECLS as a last resort, efficient, and relatively safe therapeutic option in this population. However, the uncontrolled nature of our data requires careful interpretation.

\section{Introduction}

Drug-induced cardiovascular failure is the leading cause of death in severe acute drug intoxication [1,2]. In this setting, patients with refractory shock or cardiac arrest who do not respond to optimal conventional treatment may need special therapies, such as extracorporeal life support (ECLS). Although cardiovascular bypass is rarely used in the management of poisoning, it may have potential benefits for hemodynamic instability not responding to conventional measures. Promising results have been obtained using temporary circulatory support in several single-case reports [3-17] and short series $[18,19]$. However, the usefulness of cardiovascular bypass in drug-induced cardiac failure remains unclear [20]. The aim of the study was to describe our 10-year experience of ECLS as a last resort therapeutic option in acute poisoning. Seven of the cases included in this series were previously published $[15,18]$.

\section{Materials and methods}

We reviewed the cases of all patients treated with emergency cardiopulmonary bypass for prolonged cardiac arrest or cardiogenic shock following drug intoxication at the University Hospital of Caen between 1997 and 2007. Our medical teams and nurses have a large amount of experience with

ACT: activated clotting time; CPC: cerebral performance class; ECLS: extra corporeal life support; MSA: membrane stabilizing activity; SAPS: Simplified Acute Physiology Score; SOFA: Sequential Organ Failure Assessment. 
emergency ECLS, specifically among critically ill patients $[15,18,21,22]$.

\section{Patients}

During the study period, 721 patients were admitted for drug intoxication (Figure 1). One hundred and ten patients had hemodynamic failure responding to conventional treatment and 17 patients had refractory shock or cardiac arrest. In our practice, patients with refractory cardiac arrest, defined as an absence of return to spontaneous circulation after continuous cardio-pulmonary resuscitation over at least 45 minutes or refractory shock, defined as shock not responding to optimal conventional treatment, were candidates for ECLS support [23]. When the decision to implant ECLS was made by a senior intensivist, a senior cardiac surgeon and a perfusionist were immediately informed and ECLS performed.

\section{Data collection}

According to French legislation at the time of the study and given the observational retrospective nature of the study, no ethical committee was requested and thus no informed consent was obtained from the patients. At the time of ECLS implantation the focus was specifically on hemodynamic (including electrocardiographic and echocardiographic), neurologic, respiratory, renal, liver, and hematologic data. Measured physiological variables were used to calculate the Simplified Acute Physiology Score (SAPS II) [24] and the Sequential Organ Failure Assessment (SOFA) score [25]. The toxicological screening was recorded and drugs classified as with or without cardiotoxic effect or membrane stabilizing activity (MSA). In addition, the clinical course of each patient during hospitalization was recorded. Vascular, neurologic, hemorrhagic, renal, and perfusion system complications were

Figure 1

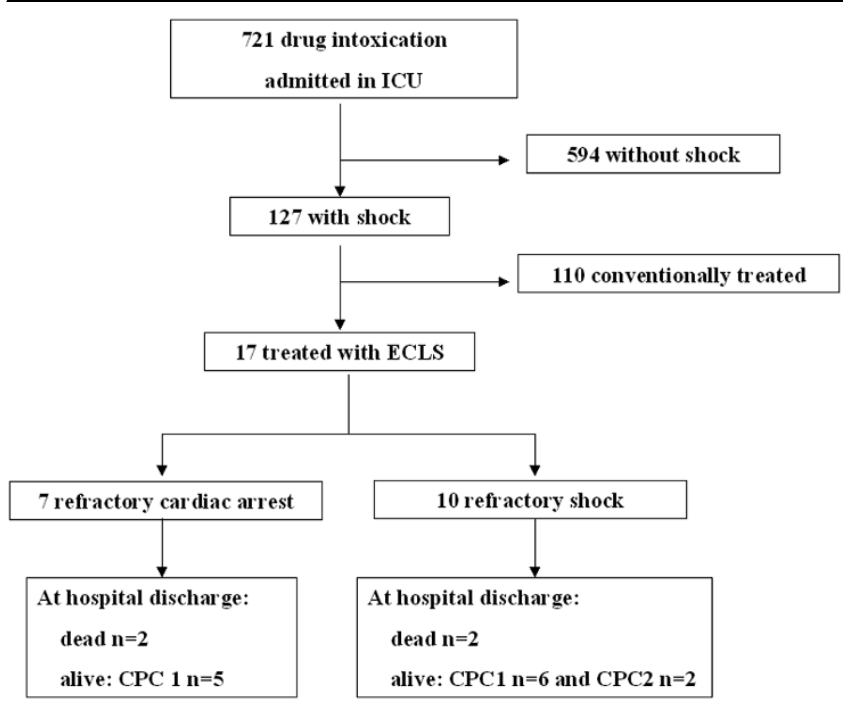

Flow chart indicating patient characteristics. CPC: cerebral performance class; ECLS: extra corporeal life support; ICU: intensive care unit. documented. The neurologic outcome at hospital discharge was assessed according to the cerebral performance class (CPC) categories [26]: CPC $1=$ good cerebral performance, CPC 2 = moderate cerebral disability, CPC $3=$ severe cerebral disability, CPC $4=$ coma or vegetative state, and CPC 5 $=$ brain death or death.

\section{Cannulation technique}

Device description, cannulation technique, management, and weaning from ECLS were previously reported in detail [22]. Briefly, the hardware for cardiopulmonary circulation consisted of a Biomedicus portable system (Medtronic, Inc, Minneapolis, MN, USA) incorporating a centrifugal pump console and a water pump system. The closed ECLS circuit consisted of pre-connected polyvinyl chloride tubing (Medtronic, Inc, Minneapolis, MN, USA) including a constrained vortex pump chamber, a hollow-fiber membrane oxygenator with an integral heat exchanger (Maxima PRF, Medtronic, Inc, Minneapolis, MN, USA), and a flow probe. All components were heparincoated (Carmeda Bioactive Surface-coating). The cannulae were Biomedicus (17 F to $25 \mathrm{~F}$ ), according to the size of patients.

Once the decision to implant ECLS support was made, the circuit was quickly primed with normal saline. Heparin was administered to the patient at $50 \mathrm{Ul} / \mathrm{kg}$ immediately before cannulation of the vessels. The activated clotting time (ACT) was kept between 150 and 200 seconds at full-flow assistance. Peripheral femorofemoral cannulation was surgically set up using a modified Seldinger technique. Because cannulation-related limb ischemia was a major problem when we began this technique, additional distal limb perfusion was inserted to avoid severe leg ischemia. The distal tip of the arterial cannula was positioned in the common iliac artery or distal abdominal aorta, whereas the tip of the venous cannula was set in the right atrium under echocardiographic guidance and confirmed by chest radiograph.

\section{Patient management during ECLS}

Pump flow was initially set at $2.5 \mathrm{~L} / \mathrm{m}^{2}$ and vasopressor (norepinephrine and epinephrine) was used to maintain a mean blood pressure of at least $60 \mathrm{mmHg}$. An inotropic support was used even if systemic perfusion was adequately performed by ECLS to maintain a pulsatile flow through the native heart. The aim was to decompress the left heart and minimize stasis, therefore reducing the risk of intracardiac thrombosis. If necessary, to accomplish mechanical decompression of the left heart, an atrial balloon septostomy was performed. A femoral vein approach was used in which a transeptal puncture, followed by blade septostomy, was performed under combined radioscopy and echocardiographic guidance. Sequential balloon inflations were carried out to achieve left heart decompression, which was confirmed by echocardiography. The ECLS was monitored by trained ICU personnel. A perfusionist was also available for occasional monitoring visits and emer- 
gencies. Echocardiography was used serially to assess progressive myocardial recovery and exclude intracardiac thrombosis or other abnormalities. All patients were mechanically ventilated with 5 to $6 \mathrm{~mL} / \mathrm{kg}$ tidal volume and 8 to 10 $\mathrm{cmH}_{2} \mathrm{O}$ positive end-expiratory pressure, and continuous venovenous hemofiltration was used to treat acute renal failure and regulate the intravascular volume and overall fluid balance, if necessary.

\section{Weaning}

The decision to discontinue ECLS support was based on evidence of multiorgan failure, overwhelming sepsis, or severe neurological injury. Patients were weaned off ECLS if the left ventricular ejection fraction, assessed by echocardiography during a reduction of pump flow to 500 to $1000 \mathrm{~mL} / \mathrm{min}$, was stable (> 50\%) without deterioration in hemodynamic status. During this period, anticoagulation was adapted to adequate values of ACT (250 to 300 seconds). If the patient's cardiovascular status remained stable, ECLS was withdrawn by cardiac surgeons.

\section{Statistical analysis}

Quantitative and qualitative data are expressed as mean $( \pm$ standard deviation), or median (range) and percentage, respectively.

\section{Results \\ Patients and drugs}

Seventeen patients ( 11 females, 6 males; mean age $39 \pm 18$ years) were treated with ECLS following drug intoxication. All patients, except two, had ingested cardiotoxic drugs, including 11 cases of drugs with MSA. The majority (12/17) of poisonings resulted from mixed poisonings involving a combination of cardiotoxic drugs, various psychotic drugs, and alcohol (Table 1).

\section{Baseline characteristics}

The baseline characteristics of patients at the time of ECLS implantation are reported in Table 2. All patients, except two, were comatose. The patients' median SAPS II score was 69 (26 to 82) and median SOFA score was 13.5 (3 to 18). The ECLS setup was performed for 13 patients in the operating room, 3 in the intensive care unit, and 1 in the emergency department. Seven patients received ECLS during external cardiac massage for refractory cardiac arrest, which occurred in six cases at hospital admissions in the emergency room. Ten other patients also received ECLS, including two after the restoration of spontaneous circulation following a brief period of asystole, during refractory shock. The mean duration of external cardiac massage was $101 \pm 55$ minutes.

Table 1

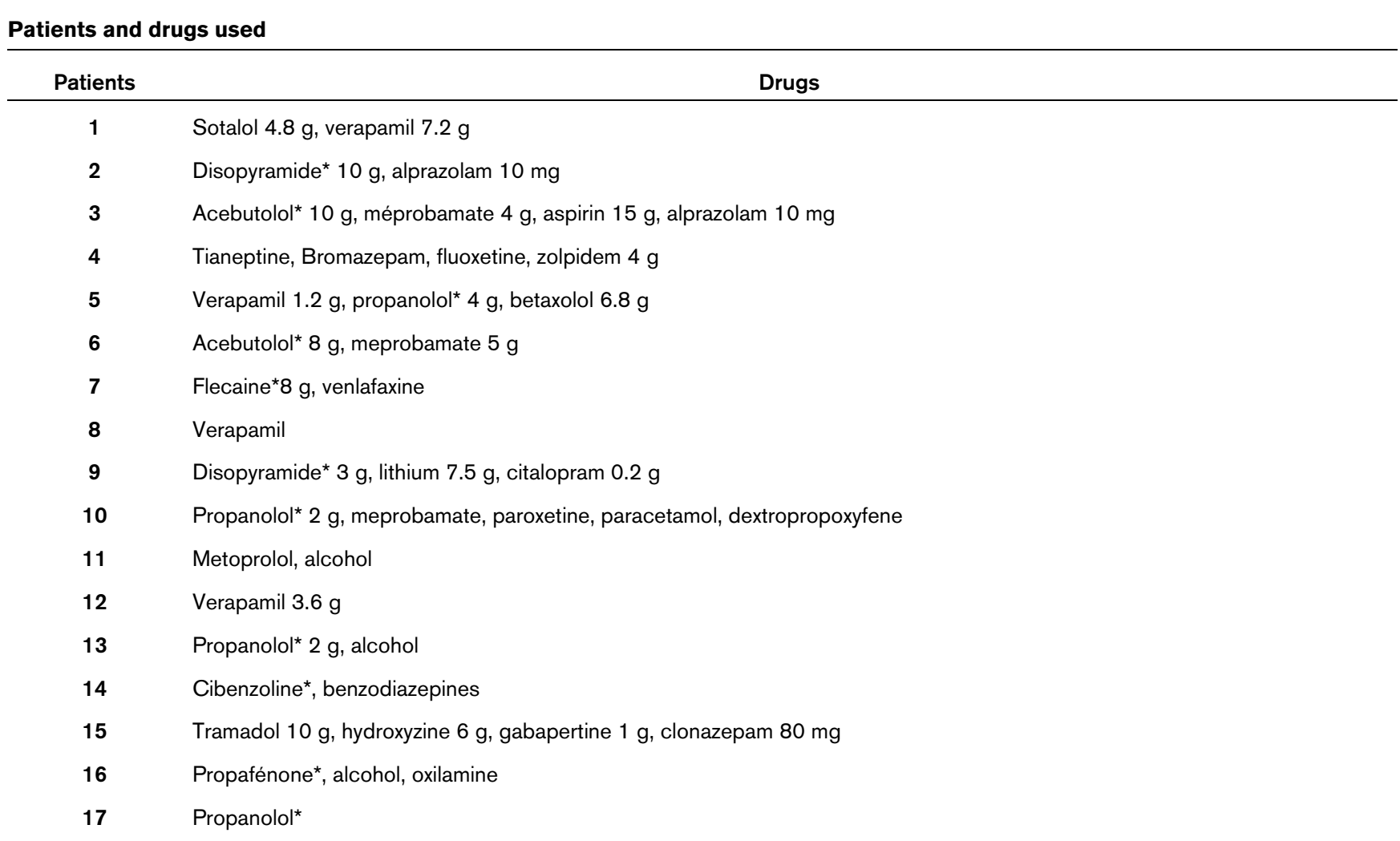

\footnotetext{
* Drugs with membrane stabilizing activity (MSA).
} 
Table 2

\begin{tabular}{|c|c|c|c|c|c|c|c|c|c|}
\hline $\mathrm{N}^{\circ}$ & $\mathrm{ECM}(\min )$ & GCS & HR & AP $(\mathrm{mmHg})$ & Vasopressor & ECG & LVEF & $\begin{array}{l}\text { Lactate } \\
\text { (mmol/L) }\end{array}$ & $\begin{array}{c}\text { Bicarbonate } \\
(\mathrm{mmol} / \mathrm{L})\end{array}$ \\
\hline $1^{\S}$ & 160 & 3 & 0 & 0 & Epinephrine & Asystole & Akinesia & - & 21.1 \\
\hline $2^{\S \pi}$ & 150 & 3 & 0 & 0 & Epinephrine & Asystole & - & $>30$ & 17.8 \\
\hline $3 \S \pi$ & 170 & 3 & 0 & 0 & $\begin{array}{l}\text { Epinephrine } \\
\text { Isoproterenol }\end{array}$ & Asystole & Akinesia & 10.8 & 19 \\
\hline 4 & 60 & 3 & 40 & $60 / 40$ & Epinephrine & $\begin{array}{c}\text { Bradycardia } \\
\text { (QRS } 183 \mathrm{~ms} \text { ) }\end{array}$ & $\begin{array}{l}\text { Hypokinesia } \\
\text { (LEVF 15\%) }\end{array}$ & 5.85 & 29.6 \\
\hline 5 & 70 & 3 & 0 & 0 & Epinephrine & Asystole & - & 7.3 & 26.3 \\
\hline 6 & 50 & 3 & 0 & 0 & - & Asystole & Akinesia & - & - \\
\hline 7 & 60 & 3 & 30 & $50 / 33$ & $\begin{array}{l}\text { Epinephrine } \\
\text { Dobutamine }\end{array}$ & $\begin{array}{l}\text { Bradycardia } \\
\text { (QRS } 214 \mathrm{~ms} \text { ) }\end{array}$ & Akinesia & - & 17.5 \\
\hline $8 \pi$ & No & 3 & 60 & $50 / 30$ & $\begin{array}{l}\text { Epinephrine } \\
\text { Isoproterenol }\end{array}$ & Sinusal & - & 10.5 & 17.7 \\
\hline 9 & No & 3 & 40 & $85 / 54$ & $\begin{array}{l}\text { Epinephrine } \\
\text { Isoproterenol } \\
\text { Dobutamine }\end{array}$ & $\begin{array}{c}\text { Bradycardia } \\
\text { (QRS } 175 \mathrm{~ms} \text { ) }\end{array}$ & Hypokinesia & 9.65 & 19.6 \\
\hline $10 \pi$ & No & 3 & 68 & $71 / 52$ & $\begin{array}{l}\text { Epinephrine } \\
\text { Dobutamine }\end{array}$ & Sinusal & $\begin{array}{l}\text { Hypokinesia } \\
\text { (LVEF 20\%) }\end{array}$ & 0.57 & 17.2 \\
\hline 11 & No & 3 & & $60 / 48$ & $\begin{array}{l}\text { Epinephrine } \\
\text { Dobutamine }\end{array}$ & Sinusal & $\begin{array}{l}\text { Hypokinesia } \\
\text { (LVEF 20\%) }\end{array}$ & - & - \\
\hline 12 & No & 8 & 30 & $70 / 40$ & $\begin{array}{l}\text { Norepinephrine } \\
\text { Isoproterenol } \\
\text { Dopamine }\end{array}$ & $\begin{array}{l}\text { Atrio-ventricular } \\
\text { block }\end{array}$ & $\begin{array}{l}\text { Hypokinesia } \\
\text { (LVEF 25\%) }\end{array}$ & 4.6 & 17.9 \\
\hline $13^{\star \star}$ & No & 3 & 55 & $75 / 50$ & Epinephrine & Sinusal & $\begin{array}{l}\text { Hypokinesia } \\
\text { (LVEF 30\%) }\end{array}$ & 5.9 & 11.7 \\
\hline $14^{\S \pi}$ & No & 3 & 140 & $85 / 58$ & Epinephrine & $\begin{array}{l}\text { Ventricular } \\
\text { tachycardia }\end{array}$ & $\begin{array}{l}\text { Hypokinesia } \\
\text { (LVEF 20\%) }\end{array}$ & 8,8 & 20.2 \\
\hline $15^{\star \star \pi}$ & No & 3 & 85 & $82 / 56$ & $\begin{array}{l}\text { Epinephrine } \\
\text { Norepinephrine }\end{array}$ & $\begin{array}{l}\text { Right bundle- } \\
\text { branch block }\end{array}$ & $\begin{array}{l}\text { Hypokinesia } \\
\text { (LVEF 25\%) }\end{array}$ & 1.7 & 18 \\
\hline 16 & No & 15 & 60 & $70 / 60$ & Epinephrine & $\begin{array}{c}\text { Bradycardia } \\
\text { (QRS } 203 \mathrm{~ms} \text { ) }\end{array}$ & $\begin{array}{l}\text { Hypokinesia } \\
\text { (LVEF 10\%) }\end{array}$ & 3.7 & 22.4 \\
\hline 17 & No & 15 & 36 & $60 / 40$ & $\begin{array}{l}\text { Epinephrine } \\
\text { Dobutamine }\end{array}$ & Sinusal & $\begin{array}{l}\text { Hypokinesia } \\
\text { (LVEF 10\%) }\end{array}$ & 3.7 & 19.9 \\
\hline
\end{tabular}

* For patients with cardiac arrest, we provided data recorded just before cardiac arrest if available

** ECLS performed after restoration of spontaneous circulation following a brief period of asystole

$\S$ Patients with temporary external transthoracic electrostimulation before initiation of ECLS

I Patients requiring continuous venovenous hemofiltration or conventional dialysis before or immediately following ECLS implantation

AP: arterial pressure; ECG: echocardiogram; ECM: manual external cardiac massage; ECLS: extra corporeal life support; HR: heart rate; GCS:

Glasgow coma score; LVEF: left ventricular ejection fraction; QRS: duration of the complex representing ventricular depolarization on electrocardiogram.

Before the initiation of ECLS support, a severe decrease in cardiac contractility was documented by echocardiography in 14 cases. All patients were mechanically ventilated and received vasopressor. Four patients needed temporary external transthoracic electrostimulation. Six patients required continuous venovenous hemofiltration or conventional dialysis for acute renal failure before or immediately after ECLS implantation. Before connection to ECLS, the median arterial $\mathrm{pH}$ was 7.37 (7.34 to 7.41), partial presure of arterial oxygen/fraction of inspired oxygen ratio was 239 (180 to 261), serum bicarbonate concentration was $19.0 \mathrm{mmol} / \mathrm{L}$ (17.7 to 20.6$)$, plasma lactate concentration was $5.9 \mathrm{mmol} / \mathrm{L}$ (3.7 to 9.7), and serum creatinine concentration was $160 \mu \mathrm{mol} / \mathrm{L}$ (114 to 204).

\section{ECLS feasibility}

ECLS feasibility, assessed with respect to time from admission to ECLS initiation, and the percentage of successful procedures (i.e. flow rate $>2.5 \mathrm{~L} / \mathrm{m}^{2}$ and mean blood pressure $>$ $60 \mathrm{mmHg}$ ) is shown in Table 3. Time from hospital admission to initiation of ECLS was $6.4 \pm 7.0$ hours, and the time to ECLS implant was $58 \pm 11$ minutes. The mean ECLS flow rate was $3.45 \pm 0.45 \mathrm{~L} / \mathrm{min}$. The average ECLS duration was 4.5 
Table 3

\begin{tabular}{|c|c|c|c|c|c|c|}
\hline $\mathrm{N}^{\circ}$ & $\begin{array}{l}\text { Time from } \\
\text { admission to } \\
\text { initiation ECLS } \\
\text { (hours) }\end{array}$ & $\begin{array}{l}\text { Time to implant } \\
\text { ECLS }^{*}(\min )\end{array}$ & $\begin{array}{l}\text { Initial ECLS flow } \\
\text { rate (I/min) }\end{array}$ & $\begin{array}{l}\text { ECLS duration } \\
\text { (days) }\end{array}$ & $\begin{array}{l}\text { LVEF at ECLS } \\
\text { discharge }\end{array}$ & Long term surviving \\
\hline $1^{* *}$ & 2.5 & 60 & 3.5 & 2 & - & No \\
\hline $2^{* *}$ & 1.5 & 60 & 3 & 3 & - & No \\
\hline 3 & 2 hours 50 mins & 40 & 3.5 & 2.3 & $62 \%$ & Yes \\
\hline 4 & 1 & 60 & 3.5 & 2.5 & $>50 \%$ & Yes \\
\hline 5 & 1 & 60 & - & 2.5 & $76 \%$ & Yes \\
\hline 6 & 1 & 60 & 3.5 & 2.3 & - & Yes \\
\hline 7 & 6 & 60 & 3.6 & 3 & $56 \%$ & Yes \\
\hline 8 & 5 & 60 & 3.7 & 11 & - & No \\
\hline 9 & 6 & 60 & 3.4 & 5 & normal & No \\
\hline 10 & 24 & 60 & 4 & 5 & $42 \%$ & Yes \\
\hline 11 & 4 & 60 & - & 4 & $38 \%$ & Yes \\
\hline 12 & 2 & 60 & 4 & 6 & $>50 \%$ & Yes \\
\hline 13 & 2.5 & 45 & 2.6 & 7 & $74 \%$ & Yes \\
\hline 14 & 15 & 90 & 4 & 6 & $45 \%$ & Yes \\
\hline 15 & 16 & 60 & 2.5 & 8 & $45 \%$ & Yes \\
\hline 16 & 3 & 60 & 3.5 & 4 & $50 \%$ & Yes \\
\hline 17 & 17 & 40 & 3.5 & 3 & $40 \%$ & Yes \\
\hline
\end{tabular}

* Delay between ECLS decision and time at which ECLS flow was provided

** Patients dead during ECLS assistance

ECLS: extra corporeal life support; LVEF: left ventricular ejection fraction.

\pm 2.4 days. In one patient (no. 17), an atrial balloon septostomy was performed to accomplish mechanical decompression of the left heart.

\section{ECLS complications}

Significant cannulation-related injuries of femoral vessels were reported in 10 patients: six patients with limb ischemia requiring urgent revascularization in three cases, one femoral thrombus, one cava inferior thrombus, and two cases of severe bleeding at the site of cannulation requiring a surgical revision.

\section{Clinical outcome}

Fifteen patients were weaned off ECLS support and two patients withdrawn from support because of refractory multiorgan failure and cerebral death (Table 3 ). Thirteen patients survived and were discharged to hospital without significant cardiovascular or neurological sequelae (CPC $1 \mathrm{n}=9$ and CPC $2 n=4)$. Two patients died of septic shock and cerebral death during the hospital stay.

\section{Discussion}

We report one of the largest series of drug-induced cardiac arrest and refractory shock managed with ECLS. The high sur- vival rate $(76 \%)$ reported in this setting supports ECLS as an efficient rescue treatment in a subset of patients with druginduced circulatory failure not responding to optimal conventional treatment.

\section{Patients and drugs}

Clinical experience with emergency ECLS during poisoning leading to prolonged cardiac arrest or shock that does not respond to conventional treatment is limited [3-19]. Poly-intoxication including cardiotoxic drugs with MSA, which is known to be associated with a high mortality rate [27], was involved in a majority of cases, as previously reported [28]. All patients were in prolonged cardiac arrest or refractory shock according to the definitions proposed by Baud and colleagues [28].

\section{ECLS feasibility and efficiency}

We confirmed the feasibility of emergency ECLS in accordance with previous reports focusing on prolonged cardiac arrest regardless of the cause $[19,22]$. The physiologic objective was to provide temporal circulatory support to the vital organs and unload the failing heart as the injured myocardium attempts to recover. In previous cohort studies [19,22], survival rates were clearly higher in the toxic cardiac arrest group, 
as compared with other causes of cardiac arrest ( 3 of 12 vs 0 of 5 [19] and 4 of 6 vs 4 of 34 [22], respectively). The high survival rate (76\%) reported in our cohort was in accordance with the general survival rate from $58 \%$ (15 of 26 ) in case reports of poisoned patients who benefited from ECLS [3$14,16,17,19]$. The 5 of $7(71 \%)$ survival rate we reported among patients with cardiac arrest was in contrast with the dramatically low survival rate of $7 \%$ and $4.5 \%$, respectively, reported in overdoses involving cardiac arrest $[29,30]$. To our knowledge, no studies have reported the survival rate of patients with drug-induced cardiovascular shock apparently refractory to conventional treatment, limiting comparisons with our cohort. However, experimental studies with control groups demonstrated that ECLS improved survival in animal models of severe cardiotoxic drug-induced shock [31,32]. These results suggest that ECLS could be considered as a good emergency resuscitative tool in this setting.

\section{ECLS complications}

Severe cannulation-related limb ischemia was the major problem when we first started the technique. Therefore, to accomplish a perfusion of the distal limb, surgeries performed an additional arterial shunt with a small $8 \mathrm{~F}$ catheter between the side port of arterial cannula and a point located some centimeters distally in the superficial femoral artery shunt. After this supplementary shunt was added, only distal embolic ischemia were reported. In contrast to Mégarbane and colleagues [19], the rate of cannulation-related complications, limb ischemia, and major bleeding was relatively high despite the modified Seldinger technique and additional distal limb perfusion. These differences could be explained by a higher ECLS duration in our study. However, our results were in accordance with reports of significant morbidity associated with emergency ECLS [33]. In addition, no death was induced by cannulation-related complications, and all survivors were discharged without significant cardiovascular or neurological sequelae.

\section{Limitations}

Firstly, because ECLS indication for drug overdose is rare, the sample size is small. Secondly, the uncontrolled retrospective observational design does not permit clarification of the role of ECLS therapy in drug-induced cardiac failure in a therapeutic algorithm. However, because usefulness of ECLS in this setting remains debatable [20], we believe this study adds important information about ECLS as a rescue therapy in patients with drug-induced cardiac arrest and refractory shock.

\section{Conclusions}

Based on our experience, we consider ECLS as a last resort, efficient, and relatively safe therapeutic option in critically ill poisoned patients (i.e. cardiac arrest and refractory shock) who do not respond to conventional therapies, providing the cardiac surgeon with the means to rapidly intervene and control ECLS-related complications. However, because there is insufficient evidence concerning the use of ECLS as a treatment for severe cardiac impairment due to poisoning, further studies are needed to clarify criteria for unresponsiveness to conventional treatment and the indications of ECLS in this setting.

\section{Key messages}

- Cardiovascular failure is the leading cause of death following a cardiotoxic drug overdose.

- This report supports the hypothesis that ECLS may be considered as a last resort, efficient, and relatively safe therapeutic option in critically ill poisoned patients (i.e. cardiac arrest and refractory shock) who do not respond to conventional therapies.

\section{Competing interests}

The authors declare that they have no competing interests.

\section{Authors' contributions}

$\mathrm{CD}$ and $\mathrm{MB}$ initiated the study, and the design. $\mathrm{CD}$ and $\mathrm{PC}$ were involved in the interpretation of the results. $C D$ wrote the manuscript, and PC helped to draft the manuscript. PL, Cl, MT, $\mathrm{OL}, \mathrm{MB}, \mathrm{CQ}, \mathrm{MM}$, and PC contributed to the conception of the study and revision of the manuscript. All authors read and approved the final manuscript.

\section{Authors' information}

The work has been presented in part at the annual congress of the Société de Réanimation de Langue Française (SRLF) held in January 2008, Paris, France.

\section{Acknowledgements}

We are indebted to Dr Jean-Jacques Parienti from Department of Biostatistics and Clinical Research, Caen University Hospital, France, for his critical review of the manuscript. We thank Madame Valérie Valfong for her contribution to polishing the manuscript.

\section{References}

1. Lai MW, Klein-Schwartz W, Rodgers GC, Abrams JY, Haber DA, Bronstein AC, Wruk KM: 2005 Annual Report of the American Association of Poison Control Centers' national poisoning and exposure database. Clin Toxicol (Phila) 2006, 44:803-932.

2. DeWitt CR, Waksman JC: Pharmacology, pathophysiology and management of calcium channel blocker and beta-blocker toxicity. Toxicol Rev 2004, 23:223-238.

3. Mégarbane B, Leprince $P$, Deye N, Guerrier G, Résière D, Bloch V, Baud FJ: Extracorporeal life support in a case of acute carbamazepine poisoning with life-threatening refractory myocardial failure. Intensive Care Med 2006, 32:1409-1413.

4. Kamijo Y, Soma K, Uchimiya H, Asari Y, Ohwada T: A case of serious organophosphate poisoning treated by percutaneus cardiopulmonary support. Vet Hum Toxicol 1999, 41:326-328.

5. Auzinger GM, Scheinkestel CD: Successful extracorporeal life support in a case of severe flecainide intoxication. Crit Care Med 2001, 29:887-890.

6. Williams JM, Hollingshed MJ, Vasilakis A, Morales M, Prescott JE, Graeber GM: Extracorporeal circulation in the management of severe tricyclic antidepressantoverdose. Am J Emerg Med 1994, 12:456-458. 
7. Goodwin DA, Lally KP, Null DM Jr: Extracorporeal membrane oxygenation support for cardiac dysfunction from tricyclic antidepressant overdose. Crit Care Med 1993, 21:625-627.

8. McVey FK, Corke CF: Extracorporeal circulation in the management of massive propranolol overdose. Anaesthesia 1991, 46:744-746.

9. Rooney M, Massey KL, Jamali F, Rosin M, Thomson D, Johnson $\mathrm{DH}$ : Acebutolol overdose treated with hemodialysis and extracorporeal membrane oxygenation. J Clin Pharmacol 1996, 36:760-763.

10. Yoshida K, Kimura K, Hibi K, Nemoto T, Iwasawa Y, Hongo Y, Sugiyama M, Ishikawa T, Kuji N, Tochikubo O, Ishii M: A patient with disopyramide intoxication rescued by percutaneous cardiopulmonarysupport. J Cardiol 1998, 32:95-100.

11. Tecklenburg FW, Thomas NJ, Webb SA, Case C, Habib DM: Pediatric ECMO for severe quinidine cardiotoxicity. Pediatr Emerg Care 1997, 13:111-113.

12. Yasui RK, Culclasure TF, Kaufman D, Freed CR: Flecainide overdose: is cardiopulmonary support the treatment? Ann Emerg Med 1997, 29:680-682.

13. Corkeron MA, van Heerden PV, Newman SM, Dusci L: Extracorporeal circulatory support in near-fatal flecainide overdose. Anaesth Intensive Care 1999, 27:405-408.

14. Holzer M, Sterz F, Schoerkhuber W, Behringer W, Domanovits $\mathrm{H}$, Weinmar D, Weinstabl C, Stimpfl T: Successful resuscitation of a verapamil-intoxicated patient with percutaneous cardiopulmonary bypass. Crit Care Med 1999, 27:2818-2823.

15. Daubin C, Quentin C, Goullé JP, Guillotin D, Lehoux P, Lepage O, Charbonneau P: Refractory shock and asystole related to tramadol overdose. Clin Toxicol (Phila) 2007, 45:961-964.

16. Kolcz J, Pietrzyk J, Januszewska K, Procelewska M, Mroczek T, Malec E: Extracorporeal life support in severe propranolol and verapamil intoxication. J Intensive Care Med 2007, 22:381-385.

17. Bilbault $P$, Pynn S, Mathien $C$, Mazzucotelli JP, Schneider F, Jaeger $A$ : Near-fatal betaxolol self-poisoning treated with percutaneous extracorporeal life support. Eur J Emerg Med 2007, 14:120-122.

18. Massetti M, Bruno P, Babatasi G, Neri E, Khayat A: Cardiopulmonary bypass and severe drug intoxication. J Thorac Cardiovasc Surg 2000, 120:424-425.

19. Mégarbane B, Leprince $P$, Deye N, Résière D, Guerrier G, Rettab S, Théodore J, Karyo S, Gandjbakhch I, Baud FJ: Emergency feasibility in medical intensive care unit of extracorporeal life support for refractory cardiac arrest. Intensive Care Med 2007, 33:758-764.

20. Purkayastha $S$, Bhangoo $P$, Athanasiou $T$, Casula $R$, Glenville $B$, Darzi AW, Henry JA: Treatment of poisoning induced cardiac impairment using cardiopulmonary bypass: a review. Emerg Med J 2006, 23:246-250.

21. Babatasi $G$, Massetti $M$, Verrier $V$, Lehoux $P$, Le Page $O$, Bruno $P G$, Khayat $A$ : Severe intoxication with cardiotoxic drugs: value of emergency percutaneous cardiocirculatory assistance. Arch Mal Coeur Vaiss 2001, 94:1386-1392.

22. Massetti M, Tasle M, Le Page O, Deredec R, Babatasi G, Buklas D, Thuaudet S, Charbonneau P, Hamon M, Grollier G, Gerard JL, Khayat $A$ : Back from irreversibility: extracorporeal life support for prolonged cardiac arrest. Ann Thorac Surg 2005, 79:178-183.

23. Conseil français de réanimation cardiopulmonaire; Société française d'anesthésie et de réanimation; Société française de cardiologie; Société française de chirurgie thoracique et cardiovasculaire; Société francaise de médecine d'urgence; Société française de pédiatrie; Groupe francophone de réanimation et d'urgence pédiatriques; Société française de perfusion; Société de réanimation de langue francaise: Guidelines for indications for the use of extracorporeal life support in refractory cardiac arrest. French Ministry of Health. Ann Fr Anesth Reanim 2009, 28:182-190.

24. Le Gall JR, Lemeshow S, Saulnier F: A new Simplified Acute Physiology Score (SAPS II) based on a European/North American multicenter study. JAMA 1993, 270:2957-2963.

25. Vincent JL, de Mendonça A, Cantraine F, Moreno R, Takala J, Suter PM, Sprung CL, Colardyn F, Blecher S: Use of the SOFA score to assess the incidence of organ dysfunction/failure in intensive care units: results of a multicenter, prospective study. Working group on "sepsis-related problems" of the European
Society of Intensive Care Medicine. Crit Care Med 1998, 26:1793-1800.

26. Cummins RO, Chamberlain DA, Abramson NS, Allen M, Baskett $P$, Becker L, Bossaert L, Delooz H, Dick W, Eisenberg M: Recommended guidelines for uniform reporting of data from out-ofhospital cardiac arrest: the Utstein Style. Task Force of the American Heart Association, the European Resuscitation Council, the Heart and Stroke Foundation of Canada, and the Australian Resuscitation Council. Ann Emerg Med 1991, 20:861-874.

27. Henry JA, Cassidy SL: Membrane stabilising activity: a major cause of fatal poisoning. Lancet 1986, 1:1414-1417.

28. Baud FJ, Megarbane B, Deye N, Leprince P: Clinical review: aggressive management and extracorporeal support for druginduced cardiotoxicity. Crit Care 2007, 11:207

29. Köppel C, Oberdisse U, Heinemeyer G: Clinical course and outcome in class IC antiarrhythmic overdose. J Toxicol Clin Toxicol. 1990, 28:433-444

30. Paredes VL, Rea TD, Eisenberg MS, Cobb LA, Copass MK, Cagle A, Martin TG: Out-of-hospital care of critical drug overdoses involving cardiac arrest. Acad Emerg Med 2004, 11:71-74.

31. Freedman MD, Gal J, Freed CR: Extracorporeal pump assistance--novel treatment for acute lidocaine poisoning. Eur J Clin Pharmacol 1982, 22:129-135.

32. Larkin GL, Graeber GM, Hollingsed MJ: Experimental amitriptyline poisoning: treatment of severe cardiovascular toxicity with cardiopulmonary bypass. Ann Emerg Med 1994, 23:480-486.

33. Magovern GJ Jr, Simpson KA: Extracorporeal membrane oxygenation for adult cardiac support: the Allegheny experience. Ann Thorac Surg 1999, 68:655-661. 